Article

\title{
Test of Different Sensitizing Dyes in Dye-Sensitized Solar Cells Based on $\mathrm{Nb}_{2} \mathrm{O}_{5}$ Photoanodes
}

\author{
Alessandro Latini * (iD) and Riccardo Panetta \\ Dipartimento di Chimica, Università degli Studi di Roma “La Sapienza”, Piazzale Aldo Moro, 500185 Roma, \\ Italy; riccardo.panetta@uniroma1.it \\ * Correspondence: alessandro.latini@uniroma1.it
}

Received: 14 March 2018; Accepted: 12 April 2018; Published: 18 April 2018

check for updates

\begin{abstract}
High-performance dyes routinely employed in $\mathrm{TiO}_{2}$-based dye-sensitized solar cells (DSSCs) were tested in cells assembled using $\mathrm{Nb}_{2} \mathrm{O}_{5}$ nanostructure-based photoanodes. The sensitizers were chosen among both metal-complex (two Ru-based, N749 and C106, and one Zn-based dye, DNF12) and metal-free organic dyes (DNF01, DNF11 and DNF15). Two different sensitization processes were performed: the one commonly used for $\mathrm{TiO}_{2}$ photoanodes, and a new process relying on high pressure by autoclavation. The assembled cells were characterized by current density-voltage $(J-V)$ curves under air mass (AM) $1.5 \mathrm{G}$ illumination and in the dark, incident photon-to-current efficiency (IPCE) measurements, and electrochemical impedance spectroscopy. The tested cells show different proportional efficiencies of the dyes under investigation for $\mathrm{Nb}_{2} \mathrm{O}_{5}-$ and $\mathrm{TiO}_{2}$-based devices. Furthermore, the results were compared with those obtained in our previous work using $\mathrm{N} 719$ anchored on $\mathrm{Nb}_{2} \mathrm{O}_{5}$. A remarkable efficiency value of $4.4 \%$ under 1 sun illumination was achieved by coupling the $\mathrm{C} 106$ dye with a nonvolatile electrolyte. This value is higher than the one attained under the same conditions by using N719.
\end{abstract}

Keywords: $\mathrm{Nb}_{2} \mathrm{O}_{5}$; metal-free organic/metal-complex dye; dye-sensitized solar cells; photovoltaic property

\section{Introduction}

After almost thirty years since their first report, dye-sensitized solar cells (DSSCs) continue to attract considerable scientific and technological interest for three main reasons:

- low cost of production;

- $\quad$ easy fabrication;

- $\quad$ wide range of applicable materials [1].

The main components determining the light-to-electric energy conversion efficiency of a DSSC are the semiconductor (electron transport material, ETM), the sensitizing dye (light absorber) and the electrolyte (redox mediator, RM). Therefore, at least as a first approximation, the spectral properties can be improved by optimizing the dye's optical characteristics, the charge injection by tailoring the dye and semiconductor energy levels' relative position, while charge transport and recombination can be enhanced by acting on the ETM, the RM and on the semiconductor/dye/electrolyte interfaces. During several years of study and investigation on DSSCs, different semiconductor metal oxides such as $\mathrm{ZnO}$, $\mathrm{Nb}_{2} \mathrm{O}_{5}, \mathrm{SnO}_{2}, \mathrm{CeO}_{2}, \mathrm{WO}_{3}, \mathrm{In}_{2} \mathrm{O}_{3}, \mathrm{SrTiO}_{3}$ and $\mathrm{Zn}_{2} \mathrm{SnO}_{4}$ have been considered as potential alternatives to the principal and more efficient ETM, $\mathrm{TiO}_{2}$ (anatase) [2-5]. Among these semiconductors, $\mathrm{Nb}_{2} \mathrm{O}_{5}$ is an especially attractive alternative to $\mathrm{TiO}_{2}$ because of its wide band gap, exceeding $3 \mathrm{eV}$, and a conduction band edge position $\left(E_{C B}\right)$ more negative than that of $\mathrm{TiO}_{2}[6,7]$. Nevertheless, such a feature is not necessarily beneficial for DSSCs. While it allows for higher open-circuit voltage, $V_{O C}$, 
it is required to be used in conjunction with a more reducing dye in order to facilitate the electron injection into the semiconductor conduction band $[8,9]$.

Thus, a compromise must be found for the $E_{C B}$ position in order to attain an efficient electron injection while maintaining a high photovoltage. Once the ETM and the RM are chosen, such a balance could be achieved by a proper sensitizing dye. All the main crystalline phases of $\mathrm{Nb}_{2} \mathrm{O}_{5}$ (pseudohexagonal, orthorhombic, tetragonal and monoclinic) possess large unit cells usually bringing about small specific surface area (SSA) [10]. $\mathrm{Nb}_{2} \mathrm{O}_{5}$-reduced SSA limits the dye loading on the photoanode, and consequently the IPCE, the short circuit current $\left(J_{S C}\right)$ and the device's energy-conversion efficiency. Therefore, different niobia morphologies aiming at increasing the number of dye anchoring sites on the semiconductor surface have been previously investigated to develop high-efficiency $\mathrm{Nb}_{2} \mathrm{O}_{5}$-based DSSCs [11-13]. Nonetheless, a full optimization of the photoanode characteristics, in addition to the semiconductor properties, which include the morphology, the crystallinity and the electronic structure, is necessary to find the best dye to use with it. Indeed, once the ETM and the RM are fixed, the number of electrons that a photoanode can produce and route to the external circuit depends on the following factors:

- $\quad$ width of the sensitizing dye HOMO-LUMO gap $\left(E_{O-O}\right)$

- number of dye-semiconductor bonds;

- $\quad$ presence or absence of dye-molecule aggregates on the surface of the semiconductor;

- excited state oxidation potential of the dye $\left(E_{O X^{*}}\right)$. The thermodynamic driving force for the electron-injection process $\left(\Delta G^{i n j}\right)$ depends on this parameter;

- oxidation potential of dye in ground state $\left(E_{O X}\right)$. This parameter is closely linked to the driving force of the dye regeneration $\left(\Delta G^{\text {reg }}\right)$;

- the ability of the dye to shield the surface of the semiconductor from the redox mediator in the electrolyte solution [14].

Table 1 reports the electrochemical parameters $E_{O-O}, E_{O X}$ and $E_{O X}{ }^{*}$, with their respective literature references, for each dye used in the present work. Furthermore, these values, together with $E_{C B}$ $\left(-0.56 \mathrm{~V}\right.$ vs. Normal Hydrogen Electrode, NHE) [15] and the redox potential of the electrolyte $\left(E_{\text {redox }}\right)$ $\left(\mathrm{I}^{-} / \mathrm{I}^{3-}, 0.35 \mathrm{~V}\right.$ vs. NHE) [16], were used to calculate the driving force of the electron-injection process $\left(\Delta G^{i n j *}\right)$ and the driving force of the dye regeneration $\left(\Delta G^{r e g *}\right)$ (see Table 1). They represent a rough estimate of the real values of $\Delta G^{i n j}$ and $\Delta G^{r e g}$, because the calculation does not take into account the semiconductor/dye/electrolyte interactions. The goal of this work is to find a high-performance dye for $\mathrm{Nb}_{2} \mathrm{O}_{5}$ photoanodes, by taking advantage of the sensitizers already successfully employed in $\mathrm{TiO}_{2}$-based DSSCs. To the best of our knowledge, none of the previous researches in the literature presents the optimization of the sensitizers for DSSCs relying on $\mathrm{Nb}_{2} \mathrm{O}_{5}$ photoanodes. The dyes were chosen among both metal-complex dyes (two Ru-based dyes, N749 and C106, and one Zn-based dye, DNF12) [17-19] and metal-free organic dyes (DNF01, DNF11 and DNF15) [20-22]. Sensitizers were chosen in such a way to cover a broad range of light absorption (from $440 \mathrm{~nm}$ to $960 \mathrm{~nm}$ ), obviously taking into account the necessity of the redox potential of the electrolyte active species $\left(\mathrm{I}^{-} / \mathrm{I}_{3}{ }^{-}\right)$ and the conduction band edge of the semiconductor to be, energetically, into the dye's absorption gap. Following these criteria, the assembled cells with wide-gap dyes (for example, DNF01) have favorable $\Delta G^{\text {reg* }}$ and $\Delta G^{i n j *}$ values. Furthermore, Table 1 shows the performances exhibited by the employed dyes in $\mathrm{TiO}_{2}$-based solar cells, and a diagram showing the energy alignment between the ETM and each dye is reported in Figure 1. The chemical structures and the IUPAC names of these dyes are reported in Figure 2 and in Table 2, respectively. They were chemisorbed on $\mathrm{Nb}_{2} \mathrm{O}_{5}$ mesoporous structures obtained and characterized as already reported in the literature (sample E) [15]. Two different sensitization processes were employed: the one commonly used for $\mathrm{TiO}_{2}$ photoanodes [23,24], and a new process performed at high pressure by autoclavation [15]. The assembled cells were tested by $J-V$ curves under Air Mass (AM) 1.5 G illumination and dark, IPCE measurements and electrochemical impedance spectroscopy (EIS). 


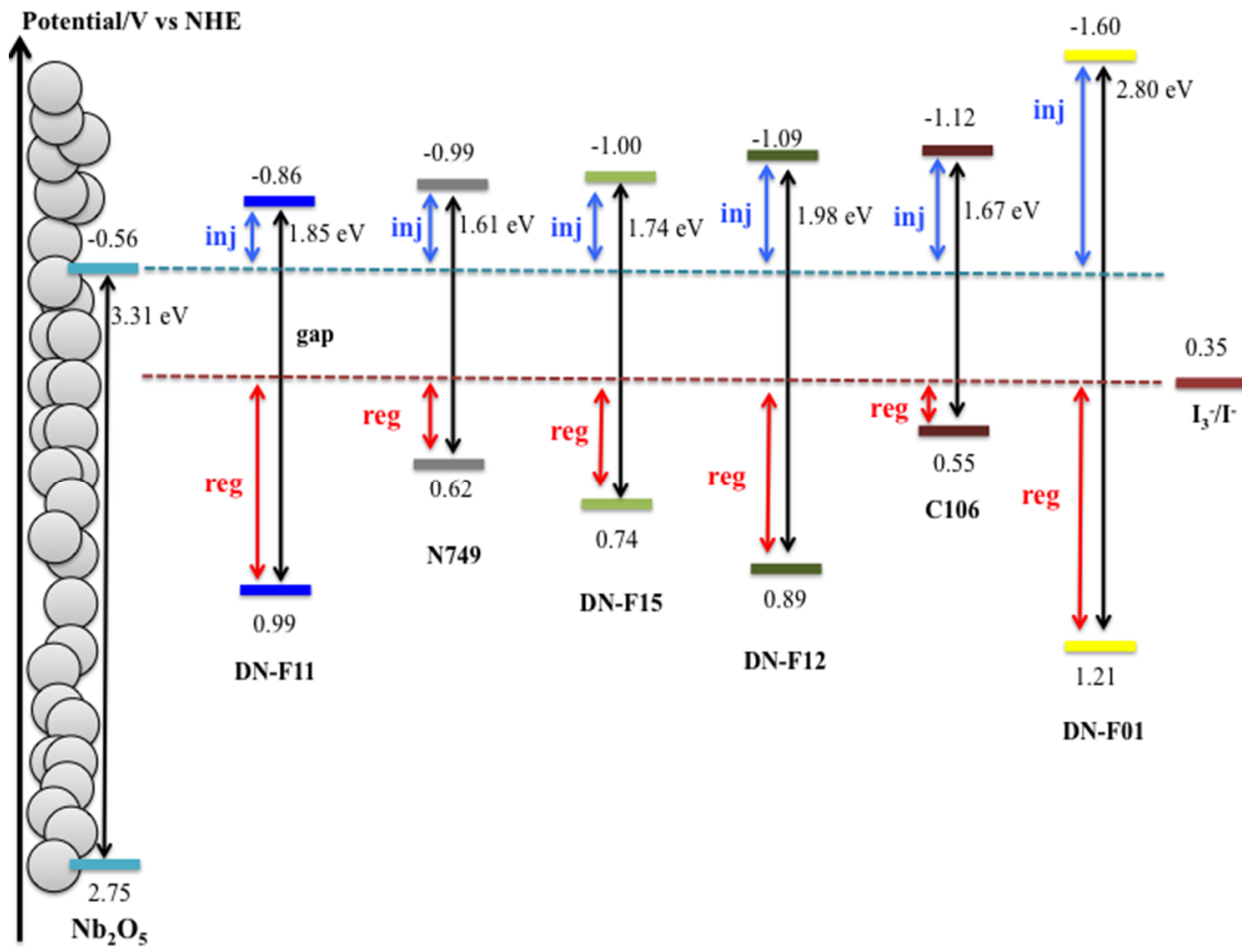

Figure 1. Schematic diagram of the relative positions of LUMO and HOMO levels of the employed dyes.

Table 1. Electrochemical parameters of the dyes, i.e., $E_{O-O}, E_{O X}(\mathrm{HOMO})$ and $E_{O X}$ (LUMO) are reported (vs. NHE). Using these values and the redox potential value of $\mathrm{I}^{-} / \mathrm{I}_{3}{ }^{-}(0.35 \mathrm{~V}), \Delta G^{i n j *}$ and $\Delta G^{r e g *}$ were calculated. Furthermore, the best performances exhibited by the same dyes in $\mathrm{TiO}_{2}$-based solar cells $\left[\eta\left(\mathrm{TiO}_{2}\right) \%\right]$ were reported, as well as the corresponding literature references.

\begin{tabular}{|c|c|c|c|c|c|c|c|}
\hline Dye & $E_{O-O} / \mathrm{V}$ & $E_{O X} / \mathrm{V}$ & $E_{O X} * / \mathrm{V}$ & $\Delta G^{i n j *} / \mathrm{kJ} \mathrm{mol}^{-1}$ & $\Delta G^{r e g *} / \mathrm{kJ} \mathrm{mol}^{-1}$ & $\eta\left(\mathrm{TiO}_{2}\right) \%$ & Ref. \\
\hline N749 & 1.61 & 0.62 & -0.99 & 41.5 & 40.5 & 10.2 & [17] \\
\hline C106 & 1.67 & 0.55 & -1.12 & 54.0 & 33.8 & 10.6 & [18] \\
\hline DNF12 & 1.98 & 0.89 & -1.09 & 51.1 & 66.6 & 6.6 & [19] \\
\hline DNF01 & 2.80 & 1.21 & -1.60 & 100 & 97.5 & 3.3 & [20] \\
\hline DNF11 & 1.85 & 0.99 & -0.86 & 28.9 & 76.2 & 7.6 & [21] \\
\hline DNF15 & 1.74 & 0.74 & -1.00 & 42.4 & 52.1 & 5.7 & [22] \\
\hline
\end{tabular}

Table 2. IUPAC names of the dyes.

\begin{tabular}{|c|c|}
\hline Dye & IUPAC Name \\
\hline N749 & $\begin{array}{l}\text { Tris }\left(N, N, N \text {-tributyl-1-butanaminium) }\left[\left[2,2^{\prime \prime} 6^{\prime}, 2^{\prime \prime} \text {-terpyridine }\right]-4,4^{\prime}, 4^{\prime \prime} \text {-tricarboxylato(3-)- }\right.\right. \\
\left.\left.N 1, N 1^{\prime}, N 1^{\prime \prime}\right] \text { tris(thiocyanato- } N\right) \text { hydrogen ruthenate( }(4-)\end{array}$ \\
\hline C106 & 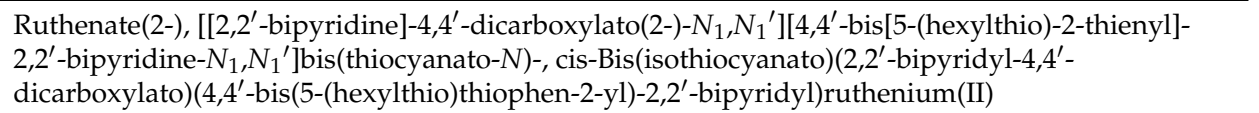 \\
\hline DNF12 & $\begin{array}{l}\text { Zinc(II) } \\
\text { 5,15-Bis(3,5-di-tert-butylphenyl)-10-(bis(4-hexylphenyl)amino)-20-(4-carboxyphenylethynyl)porphyrin }\end{array}$ \\
\hline DNF01 & 4-(diphenylamino)phenylcyanoacrylic acid \\
\hline DNF11 & $\begin{array}{l}\text { (E)-3-(5-(4-(4-(5-(4-(bis(4-(hexyloxy)phenyl)amino)phenyl)thiophen-2-yl)-2,5-bis(2-ethylhexyl)- } \\
\text { 3,6-dioxo-2,3,5,6-tetrahydropyrrolo[3,4-c]pyrrol-1-yl)phenyl)furan-2-yl)-2-cyanoacrylic acid }\end{array}$ \\
\hline DNF15 & $\begin{array}{l}\text { (3Z,4Z)-4-((5-carboxy-3,3-dimethyl-1-octyl-3H-indol-1-ium-2-yl)methylene)-2-(((E)-5-carboxy- } \\
\text { 3,3-dimethyl-1-octylindolin-2-ylidene)methyl)-3-(1-cyano-2-ethoxy-2-oxoethylidene)cyclobut-1- } \\
\text { en-1-olate }\end{array}$ \\
\hline
\end{tabular}



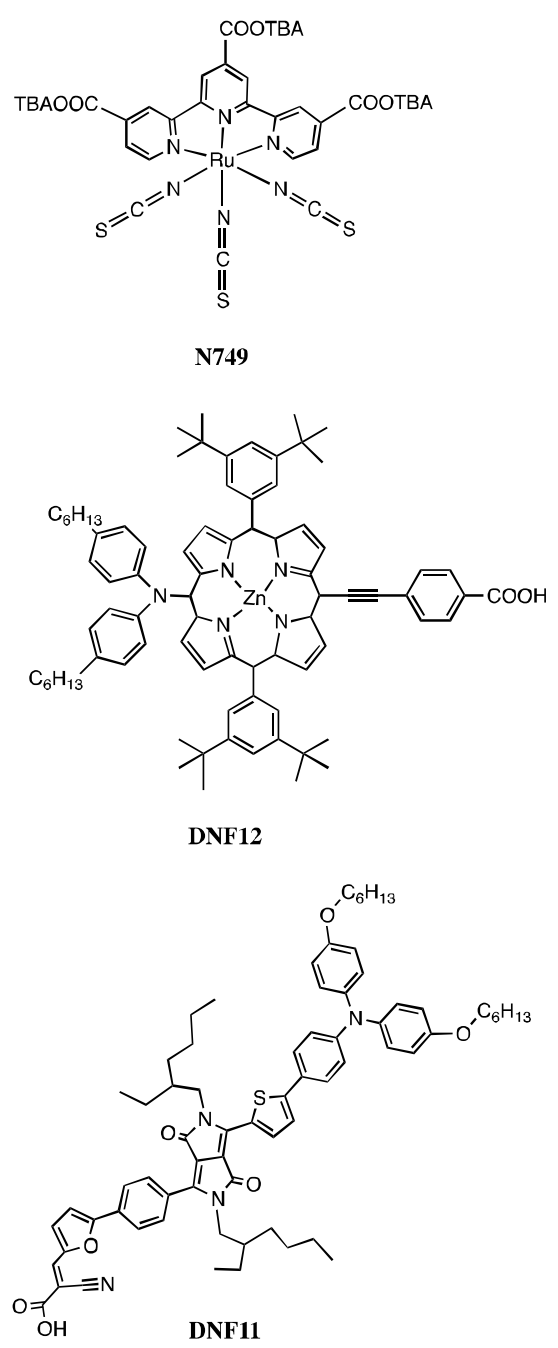

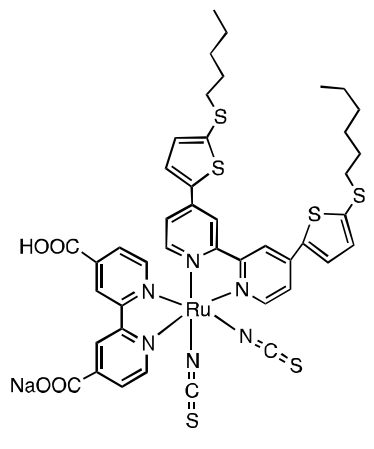

C106<smiles>CC(=Cc1ccc(N(c2ccccc2)c2ccccc2)cc1)C(=O)O</smiles>

DNF01

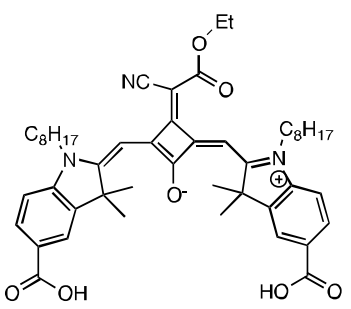

DNF15

Figure 2. Molecular structures of the dyes used in this work.

\section{Results and Discussion}

\subsection{FESEM}

Figure 3 shows the morphology of nanostructured material used to prepare the photoanodes. $\mathrm{Nb}_{2} \mathrm{O}_{5}$ forms monodisperse mesoporous spheroidal particles according to the mechanism proposed by Chen et al. [25].

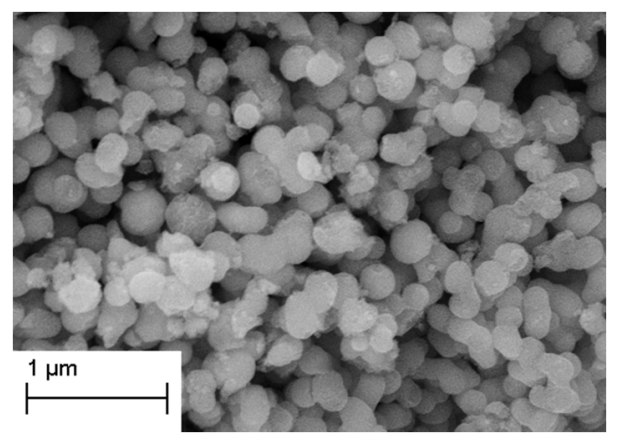

Figure 3. SEM micrograph of the $\mathrm{Nb}_{2} \mathrm{O}_{5}$ nanostructures. 


\subsection{J-V Curves under 1 Sun AM 1.5 G Illumination and in the Dark}

The DSSC parameters extracted from $J-V$ curves under illumination and in the dark are reported in Table 3, while the respective experimental curves are shown in Figures 4 and 5 (the abbreviation $h p$ refers to sensitization of $\mathrm{Nb}_{2} \mathrm{O}_{5}$ by the autoclavation process, the high-pressure sensitization). For the C106 dye, only the results obtained with the conventional sensitization process are reported, because the autoclavation process provoked the electrolyte contamination, probably due to dye molecules' aggregation on the semiconductor surface. The beneficial effect of the autoclaving process is clear (see Table 3, Figures 4 and 5) for all dyes except DNF11. The latter, similarly to C106, manifests a dye "overloading" behavior, causing electrolyte contamination, thereby decreasing the overall cell's efficiency. The best improvement, as a result of the sensitization process by autoclavation, was observed for the DNF12 dye (increase of 362\% in efficiency). On the other hand, the smallest improvement was detected for the dye DNF15 (efficiency increase 16\%). Both these results are consistent with the $\Delta G^{i n j *}$ values reported in Table 1, but mostly, with the dye coverage variation factor (see Table 6 and Section 2.4). The DNF01 dye, despite having the highest $\Delta G^{i n j *}$ and $\Delta G^{\text {reg* }}$, displays a lower efficiency enhancement than that of DNF12 (178\% efficiency increase). Probably, its high HOMO-LUMO gap (see Table 1 and normalized IPCE curves in Figure 9) and the relatively small molecular structure (see Figure 2) that limits its ability to shield the $\mathrm{Nb}_{2} \mathrm{O}_{5}$ surface from the electrolyte undermine the photoanode performance. Conversely, the DNF11 dye possesses a low $\Delta G^{i n j *}$ but a bulky structure, which should ensure a good shielding of the semiconductor carriers from the electrolyte redox shuttle, and a favorable $\Delta G^{r e g *}$. Moreover, the $V_{O C}$ and $F F$ value proved not to be affected by the autoclavation process, suggesting that the device's operating mechanism and $E_{C B}$ are not altered by the high-pressure sensitization. Among the metal-based dyes, C106 is the one that has the highest driving force for the electron-injection process (see Table 1 ). This feature could explain the very good performance of the devices assembled using this dye. The values of series resistances $\left(R_{S}\right)$ are estimated through the relationship:

$$
R_{S}=-\left(\left.\frac{d I}{d V}\right|_{V_{O C}}\right)^{-1}
$$

where $I$ and $V$ are the current and voltage in the DSSC device under illumination, respectively (see Table 3). The series resistance arises from the opposition of the cell materials (including the contacts) to current flow and, the light absorber being the only component changing in our devices, we can assume that the main differences in the $R_{s}$ value are due to the dye employed. Indeed, the total series resistance of the cell is

$$
R_{s}=R_{F T O}+R_{P t}+R_{N_{2} \mathrm{O}_{5}}+R_{D}+R_{C}+R_{d y e}
$$

where $R_{F T O}$ is the sheet resistance of the FTO glass collector, $R_{P t}$ the charge-transfer resistance at the platinized counter-electrode in the electrolyte-regeneration process, $R_{\mathrm{Nb}_{2} \mathrm{O}_{5}}$ the electron-transport resistance in the semiconductor matrix, $R_{D}$ diffusion resistance in the electrolyte, $R_{C}$ contact resistance, and $R_{\text {dye }}$ the charge-transfer resistance at photoanode (inversely proportional, at least as a first approximation, to dye amount, and depending on the dye employed). In this case, $R_{F T O}, R_{P t}, R_{\mathrm{Nb}_{2} \mathrm{O}_{5}}$, $R_{C}$ and $R_{D}$ can be considered identical for all devices, thus for each dye we can calculate a resistance difference in percent $\left(\Delta R_{S}(\%)\right)$ (see Table 4$)$ between the normal sensitization series resistance $\left(R^{n s}\right)$ and the high-pressure sensitization series resistance $\left(R^{h p}\right)$, as follows:

$$
\Delta R_{s}(\%)=\frac{R_{s}^{h p}-R_{s}^{n s}}{R_{s}^{n s}} \times 100=\frac{R_{d y e}^{h p}-R_{d y e}^{n s}}{R_{\text {dye }}^{n s}} \times 100 .
$$


Table 3. DSSC cell parameters obtained from $J-V$ curves under illumination and in the dark. The devices obtained by the high-pressure sensitization process are denoted with $h p$.

\begin{tabular}{cccccccc}
\hline Dye & $\boldsymbol{V}_{\boldsymbol{O C C}} / \mathbf{V}$ & $\begin{array}{c}\boldsymbol{J}_{\boldsymbol{S}} / \mathbf{m A} \\
\mathbf{c m}^{-\mathbf{2}}\end{array}$ & $\boldsymbol{\eta} / \mathbf{\%}$ & $\boldsymbol{F F}$ & $\boldsymbol{R s} / \mathbf{\Omega}$ & $\begin{array}{c}\boldsymbol{J}_{\mathbf{0}} / \mathbf{n} \mathbf{A} \\
\mathbf{c m}^{-2}\end{array}$ & $\boldsymbol{m}$ \\
\hline N749 & $0.5911 \pm 0.0001$ & $0.9 \pm 0.1$ & $0.36 \pm 0.03$ & $0.7 \pm 0.1$ & $660 \pm 100$ & $8 \pm 1$ & $2.06 \pm 0.01$ \\
N749 $h p$ & $0.6008 \pm 0.0001$ & $1.8 \pm 0.2$ & $0.7 \pm 0.1$ & $0.7 \pm 0.1$ & $370 \pm 100$ & $1 \pm 0.2$ & $1.85 \pm 0.01$ \\
C106 & $0.6844 \pm 0.0001$ & $9.4 \pm 0.7$ & $4.4 \pm 0.3$ & $0.7 \pm 0.1$ & $110 \pm 40$ & $11 \pm 2$ & $2.15 \pm 0.01$ \\
DNF12 & $0.5792 \pm 0.0001$ & $0.8 \pm 0.1$ & $0.26 \pm 0.02$ & $0.6 \pm 0.1$ & $730 \pm 110$ & $14 \pm 1$ & $2.16 \pm 0.01$ \\
DNF12 $h p$ & $0.5796 \pm 0.0001$ & $3.1 \pm 0.2$ & $1.2 \pm 0.1$ & $0.7 \pm 0.1$ & $240 \pm 60$ & $7 \pm 1$ & $1.97 \pm 0.01$ \\
DNF01 & $0.5717 \pm 0.0001$ & $0.5 \pm 0.1$ & $0.18 \pm 0.02$ & $0.6 \pm 0.1$ & $1160 \pm 100$ & $41 \pm 12$ & $2.48 \pm 0.01$ \\
DNF01 $h p$ & $0.6106 \pm 0.0001$ & $1.6 \pm 0.1$ & $0.50 \pm 0.04$ & $0.5 \pm 0.1$ & $940 \pm 120$ & $20 \pm 2$ & $2.388 \pm 0.003$ \\
DNF11 & $0.6444 \pm 0.0001$ & $4.1 \pm 0.4$ & $1.9 \pm 0.2$ & $0.7 \pm 0.1$ & $190 \pm 50$ & $30 \pm 6$ & $2.36 \pm 0.01$ \\
DNF11 $h p$ & $0.6444 \pm 0.0001$ & $2.3 \pm 0.2$ & $1.1 \pm 0.1$ & $0.8 \pm 0.1$ & $370 \pm 100$ & $1.7 \pm 0.2$ & $1.88 \pm 0.01$ \\
DNF15 & $0.5250 \pm 0.0001$ & $0.9 \pm 0.1$ & $0.31 \pm 0.02$ & $0.6 \pm 0.1$ & $630 \pm 110$ & $17 \pm 3$ & $2.00 \pm 0.01$ \\
DNF15 $h p$ & $0.5289 \pm 0.0001$ & $1.1 \pm 0.1$ & $0.36 \pm 0.06$ & $0.6 \pm 0.1$ & $520 \pm 130$ & $3.1 \pm 0.3$ & $1.77 \pm 0.01$ \\
\hline
\end{tabular}
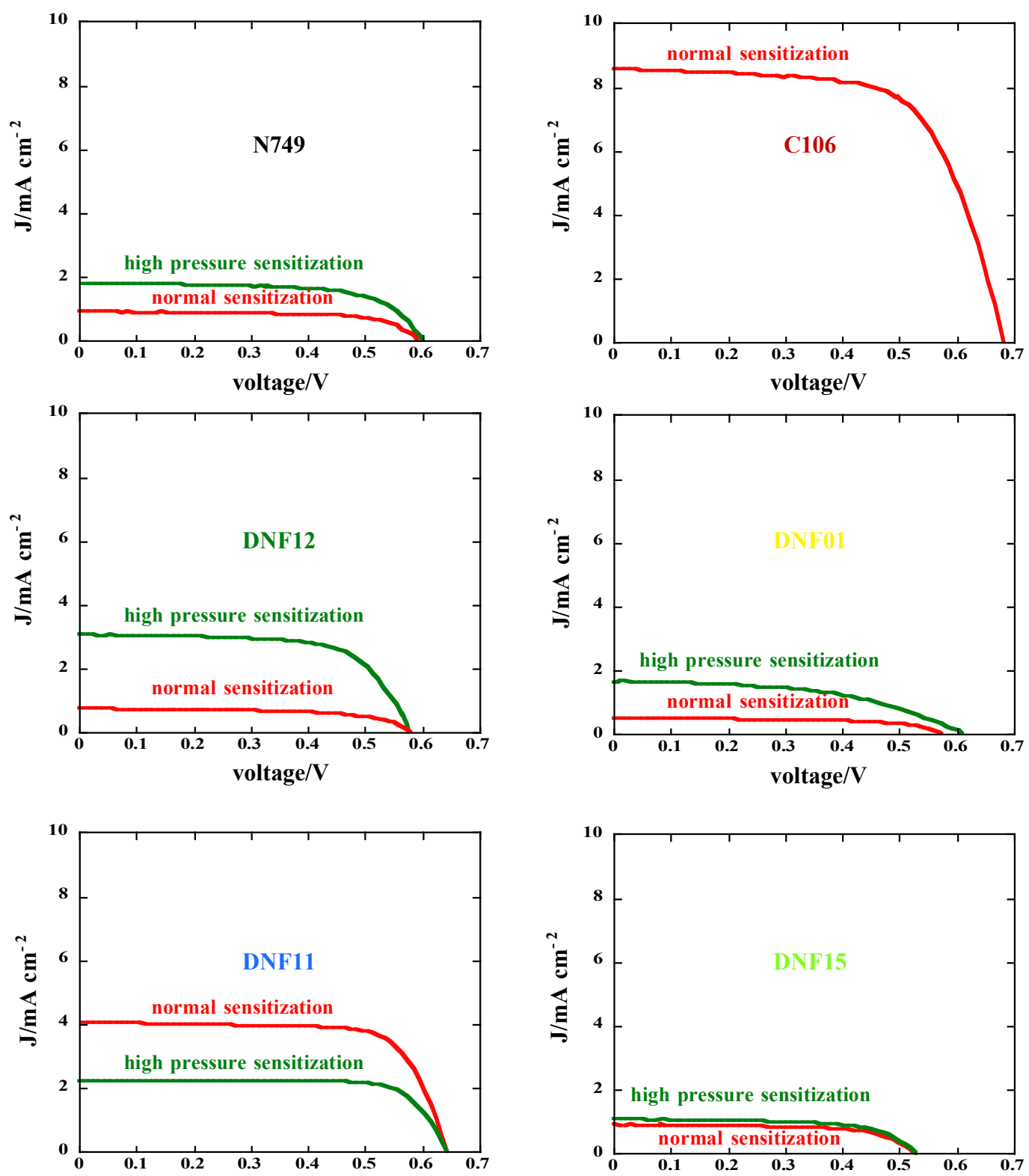

Figure 4. $J-V$ curves under irradiation. 

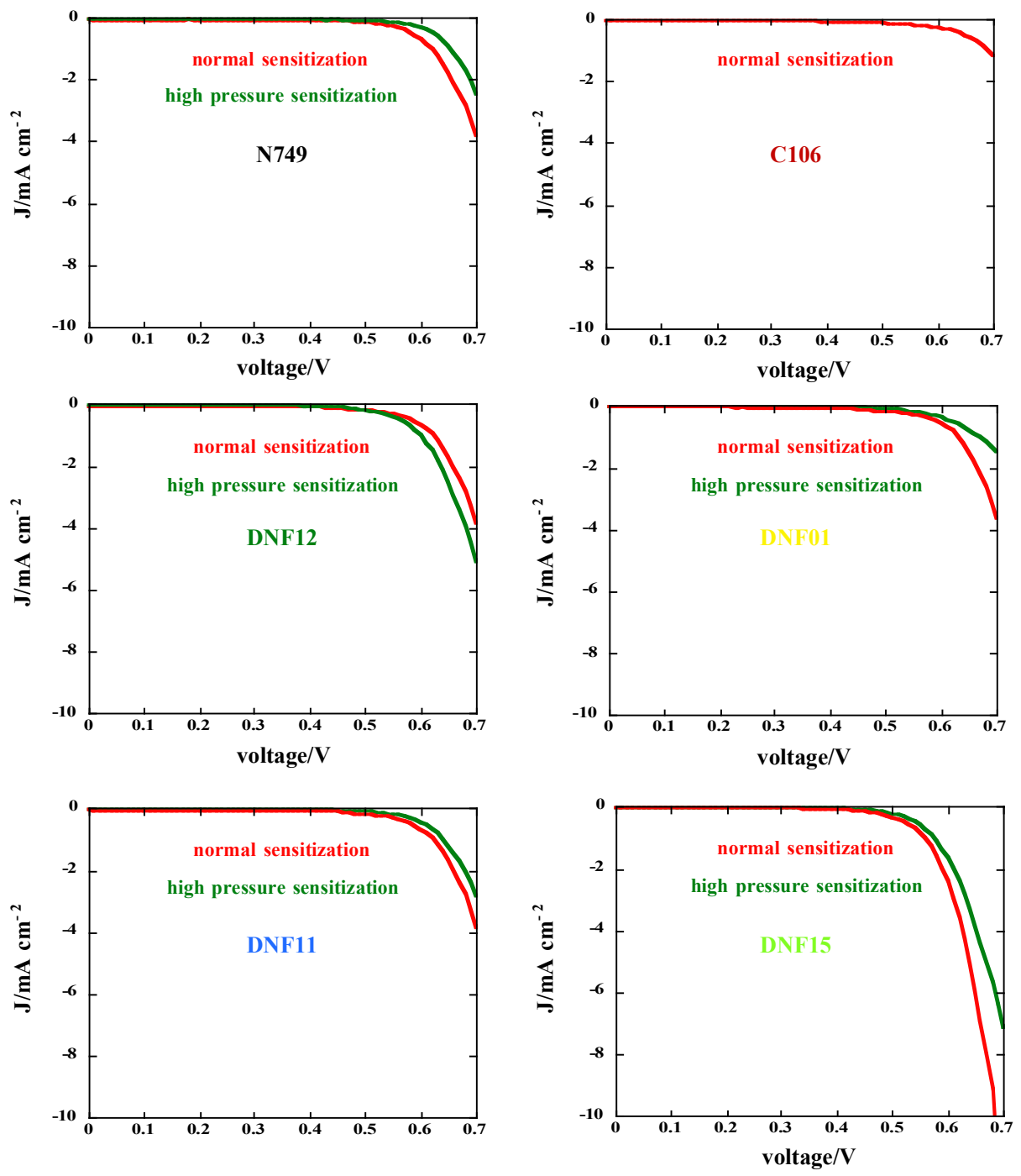

Figure 5. $J-V$ curves in the dark.

Table 4. Percent resistance difference $\left(\Delta R_{S}(\%)\right)$ between the normal sensitization series resistance and the high-pressure sensitization series resistance values.

\begin{tabular}{cc}
\hline Dye & $\boldsymbol{\Delta} \boldsymbol{R}_{\boldsymbol{s}}(\boldsymbol{\%})$ \\
\hline N749 & $-44 \pm 22$ \\
DNF12 & $-67 \pm 20$ \\
DNF01 & $-19 \pm 14$ \\
DNF11 & $95 \pm 45$ \\
DNF15 & $-17 \pm 11$ \\
\hline
\end{tabular}

The negative values indicate a decrease of the charge-transfer resistance at photoanode because of an increased amount of dye anchored on $\mathrm{Nb}_{2} \mathrm{O}_{5}$ (see Table 4$)$. Indeed, the only positive value of $\Delta R_{S}(\%)$ is found for DNF11, the only dye found to show a dye coverage decrease following autoclavation process (see Table 6). The reported $R_{S}$ values show the same trend of device efficiency (see Table 3). Furthermore, the $R_{S}$ values are consistent with the semicircle radius in Nyquist plots (see Figure 7). $J-V$ curves in the dark under forward bias (Figure 5) were acquired for all cells to obtain the values of $J_{0}$ (which gives an estimation of the recombination processes' kinetics) and the ideality factor $m$, which 
accounts for the semiconductor/dye/electrolyte interface's deviation from the ideal diode model. $J_{0}$ and $m$ calculations were carried out through the following equations:

$$
J_{d a r k}=J_{0}\left(e^{\frac{q V}{m k_{B} T}}-1\right)
$$

which, in the high-voltage region, can be simplified to:

$$
J_{\text {dark }} \approx J_{0}\left(e^{\frac{q V}{m k_{B} T}}\right)
$$

To extrapolate the values of $J_{0}$ and $m$, the Equation (8) is rearranged in the logarithmic form:

$$
\ln J_{\text {dark }} \approx \ln J_{0}+\frac{q V}{m k_{B} T} .
$$

The high values of $J_{0}$ and $m$ for the DNF01 dye explain the poor performance of the DSSCs assembled with this dye. Furthermore, we can note that, despite the good values of $J_{0}$ and $m$ for the N749 dye, the efficiencies of DSSCs assembled using such a dye are quite low, probably because of the low $\Delta G^{i n j *}$ and $\Delta G^{r e g *}$ (see Table 1). Finally, it is important to highlight the different proportional efficiency of the dyes under investigation for $\mathrm{Nb}_{2} \mathrm{O}_{5}$ and $\mathrm{TiO}_{2}$ in DSSCs, as shown in the pie charts in Figure 6. Indeed, using $\mathrm{Nb}_{2} \mathrm{O}_{5}$, the proportional DSSC efficiency of $\mathrm{C} 106$ doubled, while those of N749 and DNF15 decreased considerably compared to $\mathrm{TiO}_{2}$. This behavior, excluding DNF11 for its favorable value of $\Delta G^{\text {reg* }}$ (see Table 1 ) and its good semiconductor shielding, could be explained considering that DNF15 and N749 are the dyes with the lowest value of $\Delta G^{i n j *}$ (see Table 1). The same dyes absorbed on $\mathrm{TiO}_{2}$, on the basis of the reduction potential of the conduction band of the semiconductor ( $-0.49 \mathrm{~V}$ vs. NHE) [15], would undergo an increase of $\Delta G^{i n j *}$ values of about $30 \%$, that is, 58.9 and $57.9 \mathrm{~kJ} \mathrm{~mol}^{-1}$ for DNF15 and N749, respectively, with respect to $\mathrm{Nb}_{2} \mathrm{O}_{5}$. The same explanation (considering $\Delta G^{i n j *}$ ) justifies the increased proportional efficiency of C106 in DSSCs.
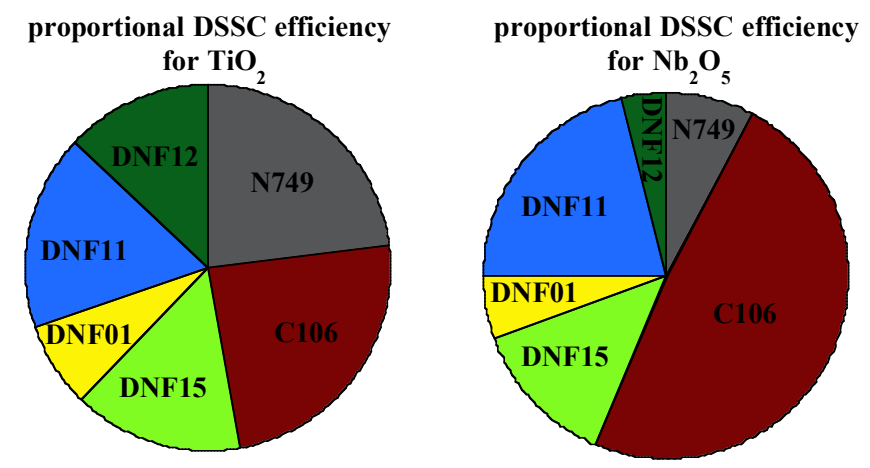

Figure 6. Pie charts of the normalized DSSC efficiency vs. dye for $\mathrm{Nb}_{2} \mathrm{O}_{5}$ and $\mathrm{TiO}_{2}$.

\subsection{Electrochemical Impedance Spectroscopy (EIS)}

The effects of the different dyes, chemisorbed on $\mathrm{Nb}_{2} \mathrm{O}_{5}$, on the electron transport and recombination kinetics in the photoanode were studied by electrochemical impedance spectroscopy. The Nyquist plots are reported in Figure 7. In general, the increase of the semicircle radius means a growth of the internal resistances of the device [26]. For the C106, DNF01 $h p$, DNF11 and DNF12 $h p$ dyes, it was found that the charge-transfer resistance values at the $\mathrm{Nb}_{2} \mathrm{O}_{5} /$ dye/electrolyte interface are comparable with those of anatase-based devices. On the other hand, for the N749 $h p$ and DNF15 $h p$, an increase of charge-transfer resistance is quite evident. The cell's Bode phase plots $\left(1-10^{4} \mathrm{~Hz}\right)$ are shown in Figure 8. The values of the electrical parameters obtained by the fit of EIS spectra using the transmission line model are reported in Table 5. The high value of the transport resistance $\left(R_{t r}\right)$ for 
the $\mathrm{Nb}_{2} \mathrm{O}_{5} / \mathrm{C} 106$ photoanode can be explained by the fact that the semiconductor is evenly coated by the dye, the semiconductor being identical for all the cells and, consequently, its contribution to $R_{t r}$. Similarly, we may reasonably justify the low value of electron diffusion length $\left(L_{e}\right)$ and therefore assign the recombination phenomena to the dye-electrolyte interface rather than to the semiconductor-electrolyte interface. This assumption is backed up by low $\Delta G^{\text {reg* }}$ for $\mathrm{C} 106$ (see Table 1). The high value of $L_{e}$ for DNF01, $70 \mu \mathrm{m}$, is in line with the relatively small dimensions of the dye molecule that facilitate the electron diffusion from dye to semiconductor. Furthermore, considering the cells assembled with the dyes DNF12 and DNF01, it is interesting note how the recombination resistance $\left(R_{r e c}\right)$ decreases with the autoclavation process. For DNF01, the decrease of $R_{r e c}$ is probably due to dye aggregation on $\mathrm{Nb}_{2} \mathrm{O}_{5}$ (see Table 6). Indeed, the intermolecular energy transfer may decrease the electron injection [20]. This hypothesis makes the high $\Delta G^{i n j *}$ value less relevant for DNF01 (see Table 1). Likewise, for DNF12, the decrease of $R_{\text {rec }}$ may be explained by the intermolecular interactions of the dye (see Section 2.4). Finally, for DNF15, the clear $R_{r e c}$ enhancement agrees with the negative trend of the chemical capacitance $\left(C_{\mu}\right)$ switching from normal sensitization to high-pressure sensitization (see Table 5). Indeed, the semiconductor-dye interactions could shift downwards the Fermi level of electrons $\left(E_{F n}\right)$ in the semiconductor, thus increasing the recombination barrier from semiconductor to dye [27]. $C_{\mu}$ and $E_{F n}$ are related by

$$
C_{\mu}=L(1-p) q g\left(E_{F n}\right)=L(1-p) q \frac{\alpha q N_{L}}{k_{B} T} \exp \left[\alpha\left(E_{F n}-E_{C B}\right) / k_{B} T\right],
$$

where $L$ is the $\mathrm{Nb}_{2} \mathrm{O}_{5}$ film thickness, $p$ its porosity, $g\left(E_{F n}\right)$ the density of bandgap states, $N_{L}$ the total density of bandgap states and $\alpha$ the parameter that describes the exponential trap distribution of electrons below the conduction band. Therefore, $L, p, N_{L}, \alpha$ and $E_{C}$ in DNF15 and DNF15 $h p$ being the same (considering that $V_{O C}$ did not change (see Table 3), it is reasonable to assume a constant value of $\left.E_{C}\right), E_{F n}$ decreases with $C_{\mu}$. On the other hand, the positive trend of $C_{\mu}$ for N749 may be related to significant IPCE spectral shift as a result of semiconductor-dye interactions (see Section 2.4).

Table 5. Transport resistance, recombination resistance, chemical capacitance, electron diffusion length and charge collection efficiency values obtained by the fit of EIS spectra using the transmission line model.

\begin{tabular}{cccccc}
\hline Dye & $\boldsymbol{R}_{\boldsymbol{t r}} / \boldsymbol{\Omega}$ & $\boldsymbol{R}_{\boldsymbol{r e c}} / \mathbf{k} \boldsymbol{\Omega}$ & $\boldsymbol{C}_{\boldsymbol{\mu}} / \mathbf{F}$ & $\boldsymbol{L}_{\boldsymbol{e}} / \boldsymbol{\mu m}$ & Charge Collection Efficiency \\
\hline N749 & $270 \pm 30$ & $4.6 \pm 0.4$ & $(1 \pm 1) \times 10^{-7}$ & $40 \pm 10$ & $0.9 \pm 0.1$ \\
N749 $h p$ & $210 \pm 10$ & $6.3 \pm 0.6$ & $(9 \pm 1) \times 10^{-6}$ & $55 \pm 10$ & $1.0 \pm 0.1$ \\
C106 & $440 \pm 50$ & $1.3 \pm 0.1$ & $(4.5 \pm 0.4) \times 10^{-5}$ & $17 \pm 1$ & $0.8 \pm 0.1$ \\
DNF12 & $200 \pm 20$ & $4.8 \pm 0.5$ & $(1.0 \pm 0.1) \times 10^{-5}$ & $50 \pm 20$ & $1.0 \pm 0.1$ \\
DNF12 $h p$ & $190 \pm 20$ & $2.9 \pm 0.3$ & $(1.1 \pm 0.1) \times 10^{-5}$ & $40 \pm 10$ & $0.9 \pm 0.1$ \\
DNF01 & $130 \pm 20$ & $6.0 \pm 0.6$ & $(1.3 \pm 0.1) \times 10^{-5}$ & $70 \pm 10$ & $1.0 \pm 0.1$ \\
DNF01 $h p$ & $110 \pm 10$ & $2.0 \pm 0.2$ & $(1.2 \pm 0.1) \times 10^{-5}$ & $40 \pm 20$ & $1.0 \pm 0.1$ \\
DNF11 & $180 \pm 20$ & $2.5 \pm 0.3$ & $(1.9 \pm 0.2) \times 10^{-5}$ & $40 \pm 10$ & $0.9 \pm 0.1$ \\
DNF11 $h p$ & $310 \pm 30$ & $5.0 \pm 0.5$ & $(1.5 \pm 0.2) \times 10^{-5}$ & $40 \pm 10$ & $0.9 \pm 0.1$ \\
DNF15 & $140 \pm 20$ & $5.2 \pm 0.5$ & $(1.4 \pm 0.1) \times 10^{-5}$ & $60 \pm 10$ & $1.0 \pm 0.1$ \\
DNF15 $h p$ & $230 \pm 30$ & $17 \pm 2$ & $(5 \pm 1) \times 10^{-6}$ & $90 \pm 30$ & $1.0 \pm 0.1$ \\
\hline
\end{tabular}

Table 6. Dye-coverage variation calculated according to Equation (8).

\begin{tabular}{cc}
\hline Dye & Dye-Coverage Variation (\%) \\
\hline N749 & 107 \\
DNF12 & 621 \\
DNF01 & 115 \\
DNF11 & -77 \\
DNF15 & 60 \\
\hline
\end{tabular}




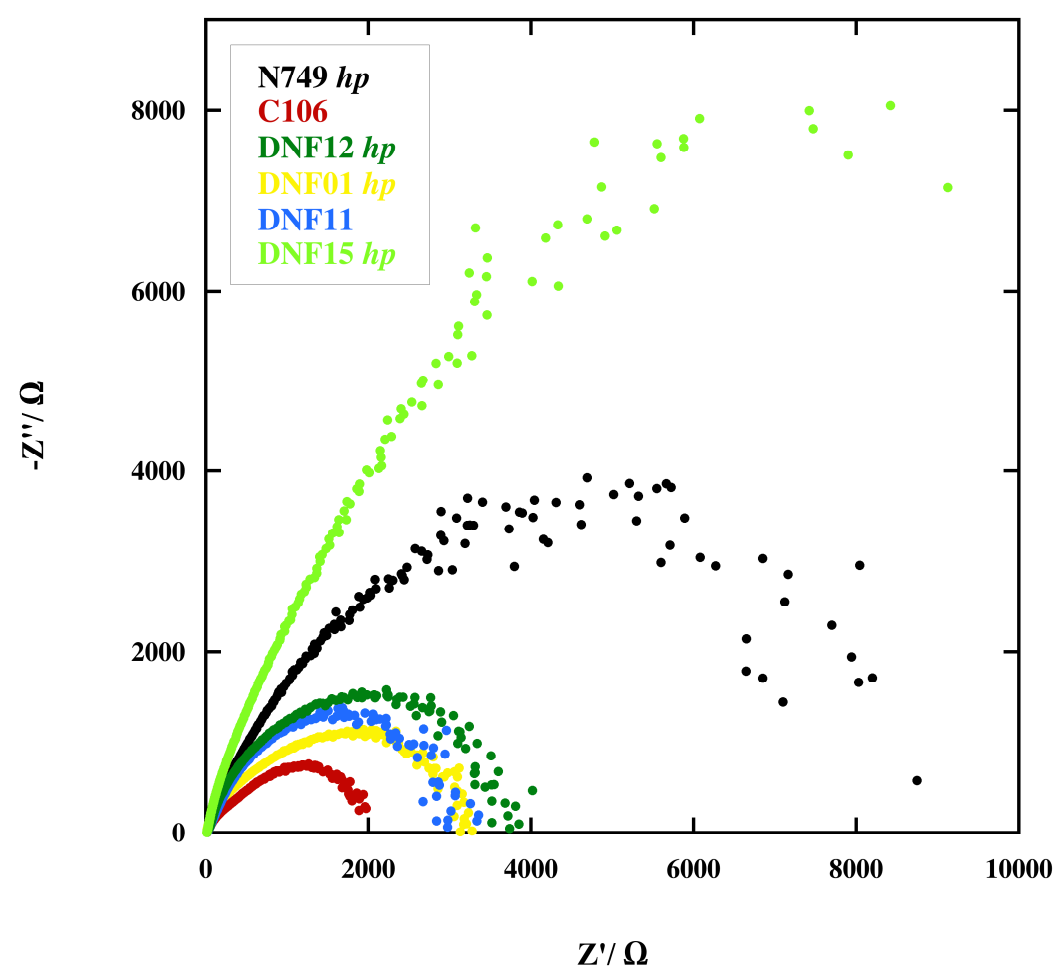

Figure 7. Nyquist plots. The devices obtained by the high-pressure sensitization process are indicated with $h p$.

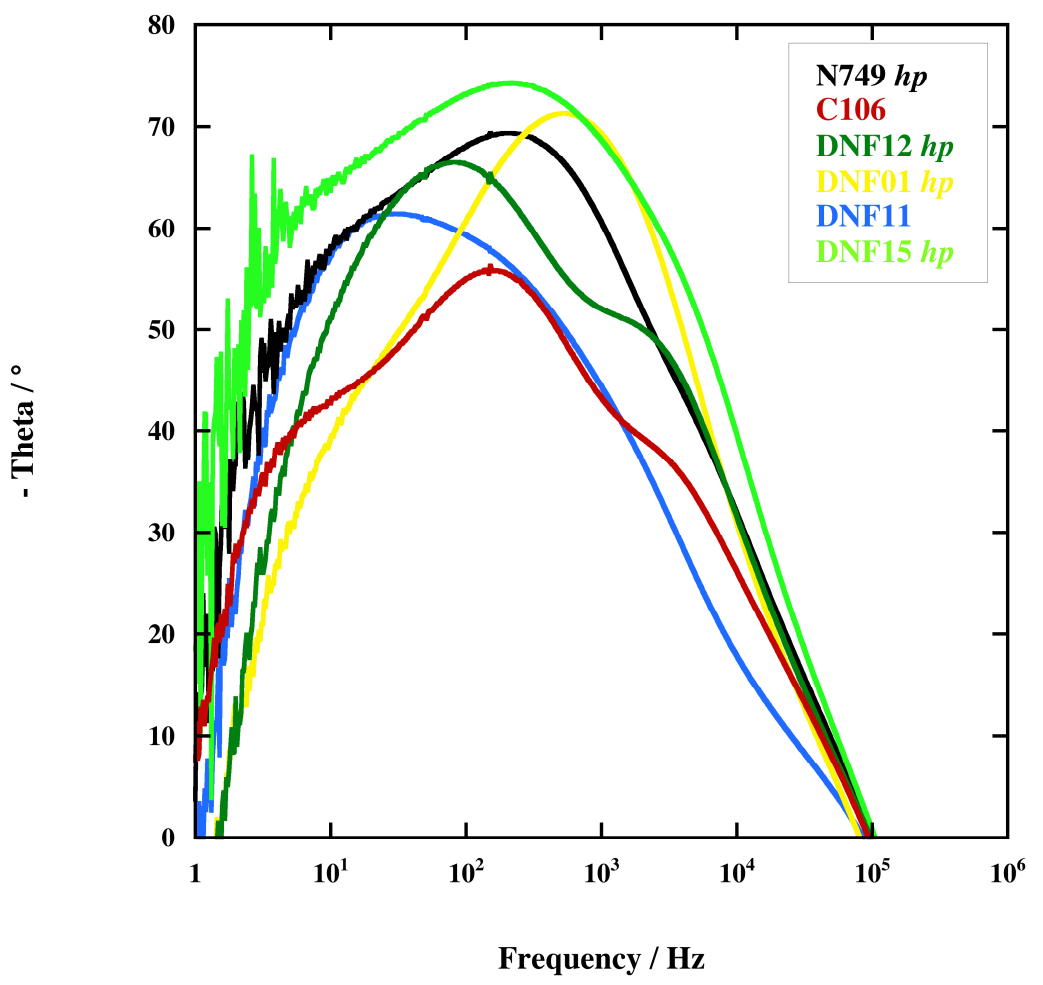

Figure 8. Bode plots. The devices obtained by the high-pressure sensitization process are indicated with $h p$. 


\subsection{Incident Photon-to-Current Efficiency (IPCE)}

In Figure 9, the normalized quantum efficiency curves for each dye are reported. These results show how the photoanodes sensitized with C106, DNF11 and N749 possess the widest absorption spectra. The IPCE spectra were used to evaluate the dye-coverage variation (\%) after the autoclavation process by calculating of IPCE area ratio as follows:

$$
\text { Dye coverage varation }(\%)=\frac{\int_{400 \mathrm{~nm}}^{800}(I P C E(h p)-I P C E) d \lambda}{\int_{400 \mathrm{~nm}}^{800 \mathrm{~m}} I P C E d \lambda} \times 100 \text {. }
$$

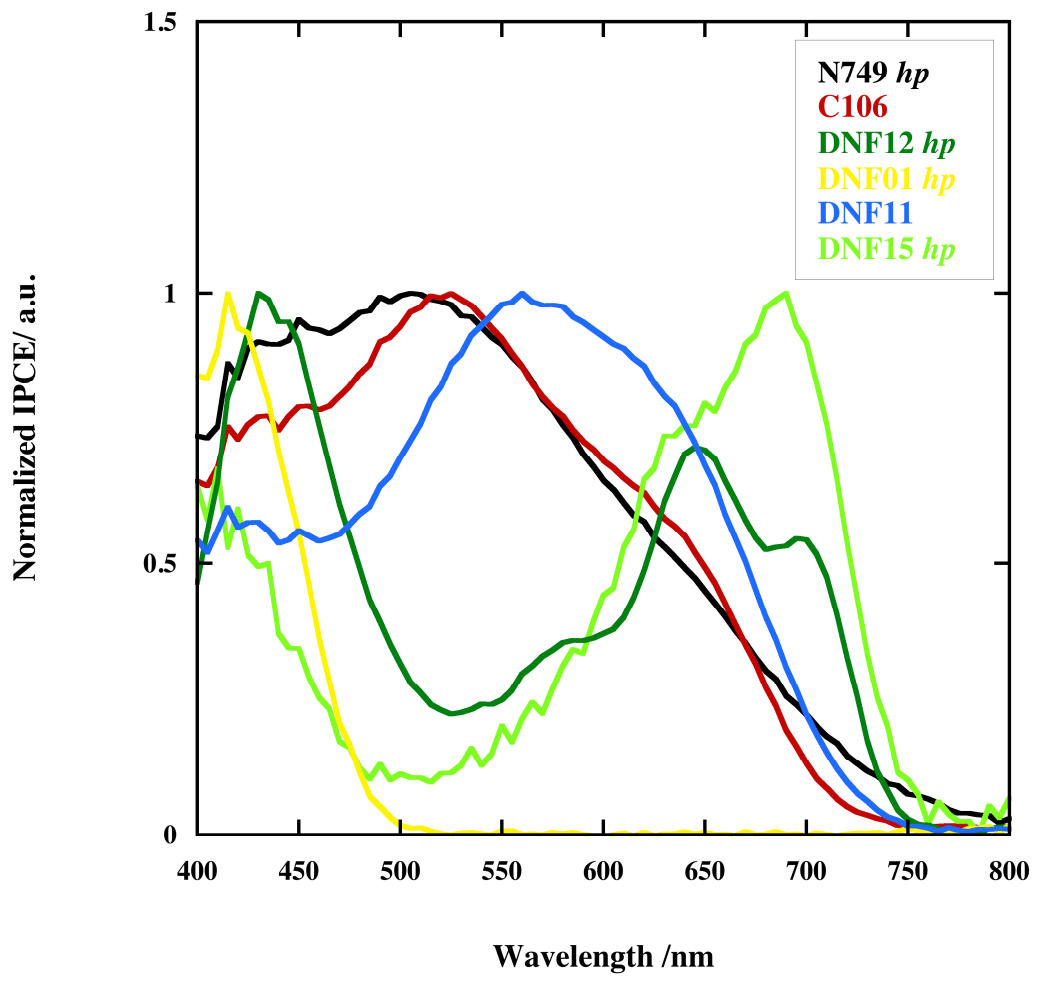

Figure 9. Normalized IPCE curves. The devices obtained by the high-pressure sensitization process are indicated with $h p$.

This evaluation is reliable because the only variable among the tested DSSCs is the amount of adsorbed dye. Furthermore, it is reasonable to exclude morphology variation because of the autoclavation process, considering the low process temperature and the insolubility of the semiconductor in the solvent used [15]. The calculated values (see Table 6) indicate a six-fold increase of dye coverage for DNF12, an about one fold increase for DNF01, DNF15 and N749, and a decrease for DNF11. The latter is in agreement with the observed electrolyte contamination in the DNF11 $h p$ DSSC, and the result achieved for DNF12 is in agreement with its $\Delta R_{s}(\%)$ value (see Table 4). Nevertheless, the value of dye-coverage variation (\%) for DNF12 appears overestimated because of the presence of a new absorption at $700 \mathrm{~nm}$ after the autoclavation process (see Figure 10b). The reason for the appearance of this additional absorption peak is not known. Furthermore, in the DNF12 spectrum, all the absorption peaks exhibit a redshift after the autoclavation process (Figure 10b). A similar behavior is displayed by N749, while DNF15 exhibits a blueshift (see Figure 10a). These results are indicative of $\Delta G^{i n j}$ e $\Delta G^{r e g}$ variations due to the autoclavation process. 

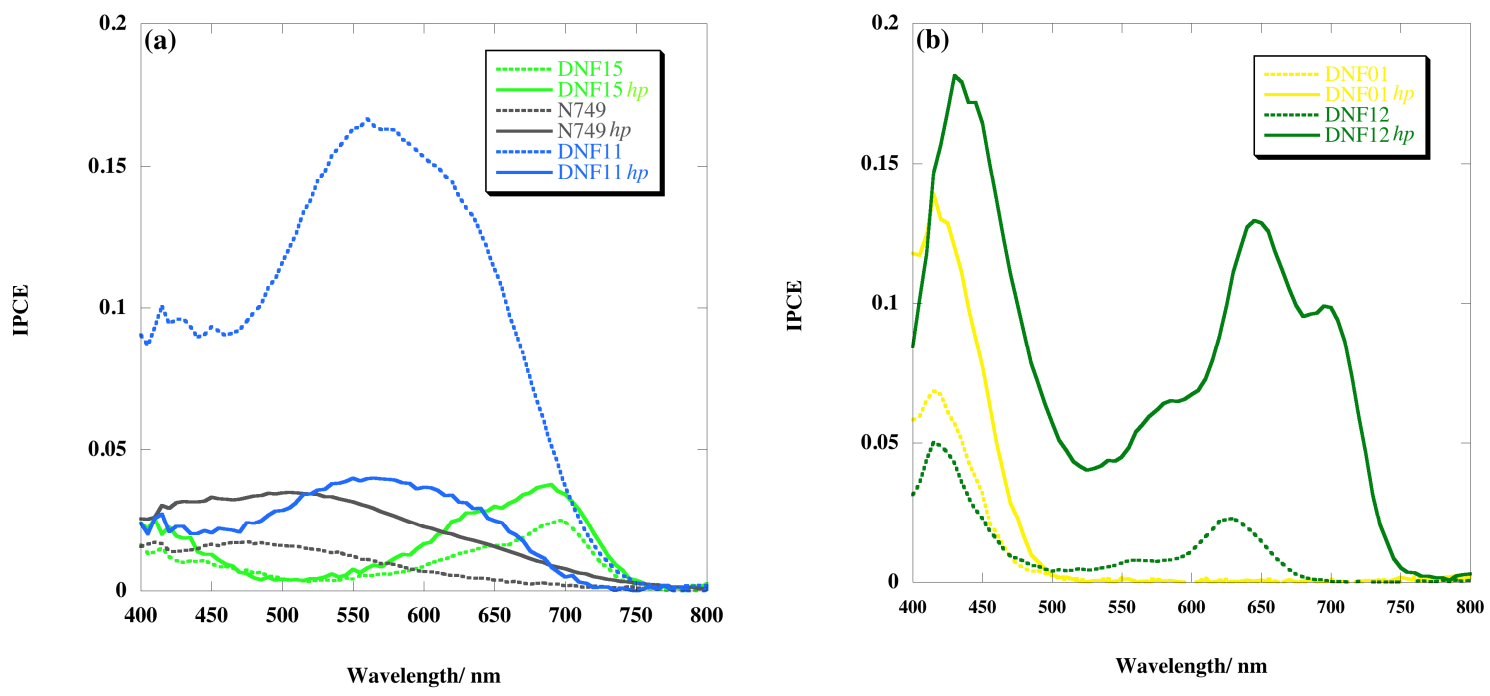

Figure 10. IPCE curves used to calculate the dye-coverage variation (\%): (a) IPCE curves of DNF15, N749 and DNF11 devices; (b) IPCE curves of DNF01 and DNF12 devices.

\section{Materials and Methods}

In this section, only the materials used for the sensitizing-solution preparation are reported. The materials used for the synthesis of $\mathrm{Nb}_{2} \mathrm{O}_{5}$ mesostructure powder, the screen-printing paste preparation, electrolyte composition and device fabrication are reported in detail in our previous work [15].

Solvents: acetonitrile (Sigma Aldrich, Milan, Italy, $\geq 99.9 \%$ ) and tert-butyl alcohol (Sigma Aldrich, $\geq 99.5 \%$ ).

Metal-based dyes: N749 (black dye, Sigma Aldrich, $\geq 85 \%$ ), C106 (Sigma Aldrich, $\geq 85 \%$ ) and DNF12 (Dyenamo, Stockholm, Sweden).

Metal-free organic dyes: DNF01 (Dyenamo), DNF11 (Dyenamo) and DNF15 (Dyenamo).

Additive: chenodeoxycholic acid (Sigma Aldrich, $\geq 97 \%$ ).

\subsection{Preparation of $\mathrm{Nb}_{2} \mathrm{O}_{5}$ Nanoparticles}

In brief, $1.99 \mathrm{~g}$ of 1-hexadecylamine (HDA) was added to $200 \mathrm{~mL}$ of 2-propanol under magnetic stirring. After HDA dissolution, $0.8 \mathrm{~mL}$ of $0.1 \mathrm{M}$ aqueous $\mathrm{KCl}$ were added to solution. Finally, 3.8 $\mathrm{mL}$ of $\mathrm{Nb}\left(\mathrm{OC}_{2} \mathrm{H}_{5}\right)_{5}$ were added and a white precipitate formed. The precipitate was left undisturbed for $24 \mathrm{~h}$ and then filtered. After filtration, the solid was autoclaved at $160^{\circ} \mathrm{C}$ for $16 \mathrm{~h}$ in a solution of water-ethanol-33\% aqueous ammonia (0.5:1:0.04). The obtained solid was calcined at $500{ }^{\circ} \mathrm{C}$ in air for $2 \mathrm{~h}$.

\subsection{DSSC Preparation and Assembly}

$\mathrm{Nb}_{2} \mathrm{O}_{5}$ photoanodes were prepared by screen printing as reported in our previous works [28-30]. The photoanode thickness used was of $10 \pm 1 \mu \mathrm{m}$. To improve the interconnectivity of the particles and the dye-adsorption properties of the photoanodes, these were impregnated with a $0.2 \mathrm{M}$ solution of $\mathrm{Nb}\left(\mathrm{OC}_{2} \mathrm{H}_{5}\right)_{5}$ [7]. For each $\mathrm{Nb}_{2} \mathrm{O}_{5}$ photoanode, two different sensitizing processes were employed: the commonly used one for anatase photoanode [28-30], and a high-pressure process [15]. In the latter, the photoanodes were autoclaved at $90^{\circ} \mathrm{C}$ for $12 \mathrm{~h}$ in $100 \mathrm{~mL}$ of sensitizing dye solution. The dye solutions' compositions were chosen according to the best ones reported in the literature for $\mathrm{TiO}_{2}$ [17-22]:

- N749: mixture of acetonitrile and tert-butyl alcohol (volume ratio: 1/1), $500 \mu \mathrm{M}$ dye concentration and $20 \mathrm{mM}$ chenodeoxycholic acid concentration;

- C106: mixture of acetonitrile and tert-butyl alcohol (volume ratio: $1 / 1), 300 \mu \mathrm{M}$ dye concentration and $2 \mathrm{mM}$ of chenodeoxycholic acid concentration; 
- DNF01: acetonitrile solution, $500 \mu \mathrm{M}$ dye concentration and $40 \mathrm{mM}$ chenodeoxycholic acid concentration;

- DNF11: mixture of acetonitrile and tert-butyl alcohol (volume ratio: 1/1), $125 \mu \mathrm{M}$ dye concentration;

- DNF12: ethanol solution, $200 \mu \mathrm{M}$ dye concentration and $400 \mathrm{mM}$ chenodeoxycholic acid concentration;

- DNF15: mixture of acetonitrile and tert-butyl alcohol (volume ratio: 1/1), $200 \mu \mathrm{M}$ dye concentration.

After the sensitization process, thesensitized $\mathrm{Nb}_{2} \mathrm{O}_{5}$ photoanodes were washed with ethanol and acetonitrile to remove the excess dye. Once dried, DSSCs were assembled using a platinized FTO glass slide as counter-electrode. Through a $1 \mathrm{~mm}$ diameter hole present on the counter-electrode, the space between the two electrodes was filled with a nonvolatile electrolyte containing $0.6 \mathrm{M}$ 1-ethyl-3-methylimidazolium iodide (EMII), 0.5 M 4-tert-butylpyridine (TBP), 0.1 M GuSCN, $0.1 \mathrm{M}$ LiI and $0.03 \mathrm{M} \mathrm{I}_{2}$ in benzonitrile [31]. A minimum of 3 cells were prepared for each dye and each sensitization process to ensure reproducibility.

\subsection{FESEM}

Field-emission scanning electron microscopy analysis of the morphology of the semiconductor was performed using a Zeiss (Oberkochen, Germany) Auriga FESEM. The SEM is equipped with a Schottky field-emission Gemini column. Operating range $100 \mathrm{~V}-30 \mathrm{kV}$. Resolution: $1.0 \mathrm{~nm}$ at $15 \mathrm{kV}$.

\subsection{DSSC Test}

The assembled devices were tested in the same way of our previous work [15]. $J-V$ curves, under simulated AM 1.5 G solar radiation and in the dark, were acquired by a Solartron Analytical (Leicester, UK) 1286 electrochemical interface (EI). The solar radiation was generated by an Asahi Spectra (Tokyo, Japan) HAL-320 class A solar simulator. Electrochemical impedance spectra (EIS) under illumination at a bias value around the maximum power-point voltage were acquired by using EI coupled with a Solartron Analytical 1260 frequency response analyzer (FRA). The data acquisition for the EI and FRA measurements was performed using the Full Combo ZPLOT/CorrWare software (version 3.3b, Scribner Associates Inc., Southern Pines, NC, USA). The fit of the impedance spectra was carried out with the ZView software (version 3.3b, Scribner Associates Inc., Southern Pines, NC, USA) using the transmission line model [32]. The incident photon-to-current conversion efficiency, IPCE, curves were recorded in DC mode using a custom-made apparatus controlled by custom-made LabVIEW-based software (version 2010, National Instruments, Austin, TX, USA).

\section{Conclusions}

In this work, different dyes, already successfully employed in $\mathrm{TiO}_{2}$-based DSSCs, were used in $\mathrm{Nb}_{2} \mathrm{O}_{5}$ photoanodes to assemble DSSC devices with a nonvolatile benzonitrile-based electrolyte. We found that the best-performing sensitizer among those tested is the C106 dye. The efficiency achieved with this dye is $4.4 \%$, under 1 sun, an improvement of $29 \%$ compared to the same semiconductor sensitized with the N719 $(\eta=3.4 \%)$, as reported in our previous work [15]. Furthermore, in the case of $\mathrm{C} 106$, it is not necessary to use the autoclavation process for the sensitization of the semiconductor. The high performance of the $\mathrm{C} 106$ is probably due to the higher driving force for the electron-injection process compared to that of N719.

Acknowledgments: The authors wish to thank Alessio Luongo for the help provided in performing all the measurements. The authors thank the Università degli Studi di Roma "La Sapienza" for financial support.

Author Contributions: The authors equally contributed to the experimental work and paper preparation.

Conflicts of Interest: The authors declare no conflicts of interest. 


\section{References}

1. O'Regan, B.; Gräzel, M. A low-cost, high-efficiency solar cell based on dye-sensitized colloidal TiO ${ }_{2}$ films. Nature 1991, 353, 737-739. [CrossRef]

2. Cavallo, C.; Di Pascasio, F.; Latini, A.; Bonomo, M.; Dini, D. Nanostructured Semiconductor Materials for Dye-Sensitized Solar Cells. J. Nanomater. 2017, 5323164. [CrossRef]

3. Chava, R.K.; Kang, M. Improving the photovoltaic conversion efficiency of $\mathrm{ZnO}$ based dye sensitized solar cells by indium doping. J. Alloys Compd. 2017, 692, 67-76. [CrossRef]

4. Chava, R.K.; Lee, W.; Oh, S.; Jeong, K.; Yu, Y. Improvement in light harvesting and device performance of dye sensitized solar cells using electrophoretic deposited hollow $\mathrm{TiO}_{2} \mathrm{NPs}$ scattering layer. Sol. Energy Mater. Sol. Cells 2017, 161, 255-262. [CrossRef]

5. Chava, R.K.; Raj, S.; Yu, Y. Synthesis and electrophoretic deposition of hollow- $\mathrm{TiO}_{2}$ nanoparticles for dye sensitized solar cell applications. J. Alloys Compd. 2016, 672, 212-222. [CrossRef]

6. Le Viet, A.; Jose, R.; Reddy, M.V.; Chowdari, B.V.R.; Ramakrishna, S. $\mathrm{Nb}_{2} \mathrm{O}_{5}$ Photoelectrodes for Dye-Sensitized Solar Cells: Choice of the Polymorph. J. Phys. Chem. C 2010, 114, 21795-21800. [CrossRef]

7. Sayama, K.; Sugihara, H.; Arakawa, H. Photoelectrochemical Properties of a Porous $\mathrm{Nb}_{2} \mathrm{O}_{5}$. Chem. Mater. 1998, 10, 3825-3832. [CrossRef]

8. Raga, S.R.; Barea, E.M.; Fabregat-Santiago, F. Analysis of the Origin of Open Circuit Voltage in Dye Solar Cells. Phys. Chem. Lett. 2012, 3, 1629-1634. [CrossRef] [PubMed]

9. Mehmood, U.; Hussein, I.A.; Harrabi, K.; Ahmed, S. Density Functional Theory Study on the Electronic Structures of Oxadiazole Based Dyes as Photosensitizer for Dye Sensitized Solar Cells. Adv. Mater. Sci. Eng. 2015, 286730. [CrossRef]

10. Alibabaei, L.; Luo, H.; House, R.L.; Hoertz, P.G.; Lopez, R.; Meyer, T.J. Applications of metal oxide materials in dye sensitized photoelectrosynthesis cells for making solar fuels: Let the molecules do the work. J. Mater. Chem. A 2013, 1, 4133-4145. [CrossRef]

11. Jin, X.; Liu, C.; Xu, J.; Wang, Q.; Chen, D. Size-controlled synthesis of mesoporous $\mathrm{Nb}_{2} \mathrm{O}_{5}$ microspheres for dye sensitized solar cells. RSC Adv. 2014, 4, 35546-35553. [CrossRef]

12. Ou, J.Z.; Rani, R.A.; Ham, M.; Field, M.R.; Zhang, Y.; Zheng, H.; Reece, P.; Zhuiykov, S.; Sriram, S.; Bhaskaran, M.; et al. Elevated Temperature Anodized $\mathrm{Nb}_{2} \mathrm{O}_{5}$ : A Photoanode Material with Exceptionally Large Photoconversion Efficiencies. ACS Nano 2012, 6, 4045-4053. [CrossRef] [PubMed]

13. Zhang, H.; Wang, Y.; Yang, D.; Li, Y.; Liu, H.; Liu, P.; Wood, B.J.; Zhao, H. Directly Hydrothermal Growth of Single Crystal $\mathrm{Nb}_{3} \mathrm{O}_{7}(\mathrm{OH})$ Nanorod Film for High Performance Dye-Sensitized Solar Cells. Adv. Mater. 2012, 24, 1598-1603. [CrossRef] [PubMed]

14. Hagfeldt, A.; Boschloo, G.; Sun, L.; Kloo, L.; Pettersson, H. Dye-Sensitized Solar Cells. Chem. Rev. 2010, 110, 6595-6663. [CrossRef] [PubMed]

15. Panetta, R.; Pettiti, I.; Latini, A.; Cavallo, C. Synthesis and Characterization of $\mathrm{Nb}_{2} \mathrm{O}_{5}$ Mesostructures with Tunable Morphology and Their Application in Dye-Sensitized Solar Cells. Mater. Chem. Phys. 2017, 202, 289-301. [CrossRef]

16. Boschloo, G.; Hagfeldt, A. Characteristics of the Iodide/Triiodide Redox Mediator in Dye-Sensitized Solar Cells. Acc. Chem. Res. 2009, 11, 1819-1826. [CrossRef] [PubMed]

17. Wang, Z.S.; Yamaguchi, T.; Sugihara, H.; Arakawa, H. Significant Efficiency Improvement of the Black Dye-Sensitized Solar Cell through Protonation of $\mathrm{TiO}_{2}$ Films. Langmuir 2005, 21, 4272-4276. [CrossRef] [PubMed]

18. Cao, Y.; Bai, Y.; Yu, Q.; Cheng, Y.; Liu, S.; Shi, D.; Gao, F.; Wang, P. Dye-Sensitized Solar Cells with a High Absorptivity Ruthenium Sensitizer Featuring a 2-(Hexylthio)thiophene Conjugated Bipyridine. J. Phys. Chem. C 2009, 113, 6290-6297. [CrossRef]

19. Kitamura, T.; Ikeda, M.; Shigaki, K.; Inoue, T.; Anderson, N.A.; Ai, X.; Lian, T.; Yanagida, S. Phenyl-Conjugated Oligoene Sensitizers for $\mathrm{TiO}_{2}$ Solar Cells. Chem. Mater. 2004, 16, 1806-1812. [CrossRef]

20. Yum, J.; Holcombe, T.W.; Kim, Y.; Rakstys, K.; Moehl, T.; Teuscher, J.; Delcamp, J.H.; Nazeeruddin, M.K.; Grätzel, M. Blue-Coloured Highly Efficient Dye-Sensitized Solar Cells by Implementing the Diketopyrrolopyrrole Chromophore. Sci. Rep. 2013, 3, 2446. [CrossRef] [PubMed] 
21. Hsieh, C.; Lu, H.; Chiu, C.; Lee, C.; Chuang, S.; Mai, C.; Yen, W.; Hsu, S.; Diau, E.W.; Yeh, C. Synthesis and characterization of porphyrin sensitizers with various electron-donating substituents for highly efficient dye-sensitized solar cells. J. Mater. Chem. 2010, 20, 1127-1134. [CrossRef]

22. Qin, C.; Numata, Y.; Zhang, S.; Yang, X.; Islam, A.; Zhang, K.; Chen, H.; Han, L. Novel Near-Infrared Squaraine Sensitizers for Stable and Efficient Dye-Sensitized Solar Cells. Adv. Funct. Mater. 2014, 24, 3059-3066. [CrossRef]

23. Ito, S.; Murakami, T.N.; Comte, P.; Liska, P.; Grätzel, C.; Nazeeruddin, M.K.; Grätzel, M. Fabrication of thin film dye sensitized solar cells with solar to electric power conversion efficiency over $10 \%$. Thin Solid Films 2008, 516, 4613-4619. [CrossRef]

24. Nazeeruddin, M.K.; Splivallo, R.; Liska, P.; Comte, P.; Grätzel, M. A swift dye uptake procedure for dye sensitized solar cells. Chem. Commun. 2003, 1456-1457. [CrossRef]

25. Chen, D.; Cao, L.; Huang, F.; Imperia, P.; Cheng, Y.; Caruso, R.A. Synthesis of Monodisperse Mesoporous Titania Beads with Controllable Diameter, High Surface Areas, and Variable Pore Diameters (14-23 nm). J. Am. Chem. Soc. 2010, 132, 4438-4444. [CrossRef] [PubMed]

26. Hsu, C.; Lee, K.; Huang, J.T.; Lin, C.; Lee, C.; Wang, L.; Tsai, S.; Ho, K. EIS analysis on low temperature fabrication of $\mathrm{TiO}_{2}$ porous films for dye-sensitized solar cells. Electrochim. Acta 2008, 53, 7514-7522. [CrossRef]

27. Barea, E.M.; Ortiz, J.; Payà, F.J.; Lazaro, F.F.; Santiago, F.F.; Santos, S.A.; Bisquert, J. Energetic factors governing injection, regeneration and recombination in dye solar cells with phthalocyanine sensitizers. Energy Environ. Sci. 2010, 3, 1985-1994. [CrossRef]

28. Latini, A.; Cavallo, C.; Aldibaja, F.K.; Gozzi, D. Efficiency Improvement of DSSC Photoanode by Scandium Doping of Mesoporous Titania Beads. J. Phys. Chem. C 2013, 117, 25276-25289. [CrossRef]

29. Latini, A.; Panetta, R.; Cavallo, C.; Gozzi, D.; Quaranta, S. A Comparison of the Performances of Different Mesoporous Titanias in Dye-Sensitized Solar Cells. J. Nanomater. 2015, 450405. [CrossRef]

30. Cavallo, C.; Salleo, A.; Gozzi, D.; Di Pascasio, F.; Quaranta, S.; Panetta, R.; Latini, A. Solid Solutions of Rare Earth Cations in Mesoporous Anatase Beads and Their Performances in Dye-Sensitized Solar Cells. Sci. Rep. 2015, 5, 16785. [CrossRef] [PubMed]

31. Latini, A.; Aldibaja, F.K.; Cavallo, C.; Gozzi, D. Benzonitrile based electrolytes for best operation of dye sensitized solar cells. J. Power Sources 2014, 269, 308-316. [CrossRef]

32. Santiago, F.F.; Belmonte, G.G.; Serò, I.M.; Bisquert, J. Characterization of nanostructured hybrid and organic solar cells by impedance spectroscopy. Phys. Chem. Chem. Phys. 2011, 13, 9083-9118. [CrossRef] [PubMed] 